\title{
Effects of Lime and Concrete Waste on Vadose Zone Carbon Cycling
}

Thaysen, Eike Marie; Jessen, Søren; Postma, D.; Jakobsen, R.; Jacques, D.; Ambus, Per; Laloy, E.; Jakobsen, Iver

Published in:

Vadose Zone Journal

Link to article, DOI:

10.2136/vzj2014.07.0083

Publication date:

2014

Document Version

Publisher's PDF, also known as Version of record

Link back to DTU Orbit

Citation (APA):

Thaysen, E. M., Jessen, S., Postma, D., Jakobsen, R., Jacques, D., Ambus, P., Laloy, E., \& Jakobsen, I. (2014). Effects of Lime and Concrete Waste on Vadose Zone Carbon Cycling. Vadose Zone Journal, 13(11).

https://doi.org/10.2136/vzj2014.07.0083

\section{General rights}

Copyright and moral rights for the publications made accessible in the public portal are retained by the authors and/or other copyright owners and it is a condition of accessing publications that users recognise and abide by the legal requirements associated with these rights.

- Users may download and print one copy of any publication from the public portal for the purpose of private study or research.

- You may not further distribute the material or use it for any profit-making activity or commercial gain

- You may freely distribute the URL identifying the publication in the public portal 


\section{Original Research}

In this work we investigate how lime and crushed concrete waste (CCW) affect carbon cycling in the vadose zone and explore whether these amendments could be employed to mitigate climate change by increasing the transport of $\mathrm{CO}_{2}$ from the atmosphere to the groundwater. We use a combination of experimental and modeling tools to determine ongoing biogeochemical processes. Our results demonstrate that lime and CCW amend ments to acid soil contribute to the climate forcing by largely increasing the soil $\mathrm{CO}_{2}$ efflux to the atmosphere.

E.M. Thaysen, P. Ambus, and I. Jakobsen, Dep. of Chemical and Biochemical Eng., Ctr. for Ecosystems and Environmental Sustainability, Technical Univ. of Denmark, DK-2800, Kongens Lyngby, Denmark; S. Jessen, Dep. of Geosciences and Natural Resource Management, Copenhagen Univ., DK-1350, Copenhagen, Denmark; D. Postma and R. Jakobsen, Geochemical Dep., Geological Survey of Denmark and Greenland, DK-1350, Copenhagen, Denmark; D. Jacques and E. Laloy, Inst. for Environment, Health, and Safety, Belgian Nuclear Research Ctr. (SCK•CEN), B-2400, Mol, Belgium. *Corresponding author (eikethaysen@ gmail.com). The authors declare no competing financial interest.

Vadose Zone J.

doi:10.2136/vzj2014.07.0083

Received 10 July 2014.

Open access

(C) Soil Science Society of America 5585 Guilford Rd., Madison, WI 53711 USA.

All rights reserved. No part of this periodical may be reproduced or transmitted in any form or by any means, electronic or mechanical, including photocopying, recording, or any information storage and retrieval system, without permission in writing from the publisher.

\section{Effects of Lime and Concrete Waste on Vadose Zone Carbon Cycling}

\author{
E.M. Thaysen,* S. Jessen, D. Postma, R. Jakobsen, \\ D. Jacques, P. Ambus, E. Laloy, and I. Jakobsen
}

In a series of mesocosm experiments, with barley (Hordeum vulgare L.) grown on podzolic soil material, we have investigated inorganic carbon cycling through the gaseous and liquid phases and how it is affected by different soil amendments. The mesocosm amendments comprised the addition of $0,9.6$, or $21.2 \mathrm{~kg} \mathrm{~m}^{-2}$ of crushed concrete waste (CCW) or $1 \mathrm{~kg}$ lime $\mathrm{m}^{-2}$. The CCW and lime treatments increased the dissolved inorganic carbon (DIC) percolation flux by about 150 and $100 \%$, respectively, compared to the controls. However, concurrent increases in the $\mathrm{CO}_{2}$ efflux to the atmosphere (ER) were more than one order of magnitude higher than increases in the DIC percolation flux. Analysis of soil solutions, coupled reactive-transport modeling studies, and a decrease in soil carbonate contents over the experiment altogether suggested that the increased ER from amended mesocosms was derived from the carbonate contained in the amendments, which, hence, mostly escaped to the atmosphere. Our results are important in the context of climate change due to the widespread application of lime to acidic soils. The CCW amendment had no adverse effects on plant growth and groundwater quality.

Abbreviations: C, carbon; CCW, crushed concrete waste; DIC, dissolved inorganic carbon; DW, dry weight; ER, efflux to the atmosphere; NEE, net ecosystem exchange; $R_{S^{\prime}}$ soil respiration; VWC, volumetric water content.

Agriculture has a pronounced effect on carbon (C) cycling in the vadose zone, enhancing both the flux of $\mathrm{CO}_{2}$ from the soil to the atmosphere (Robertson et al., 2000; Barker et al., 2007; Vermeulen, Campbell et al., 2012), $R_{s}$, and the flux of $\mathrm{CO}_{2}$ from the soil to the groundwater as dissolved inorganic carbon (DIC) (Oh and Raymond, 2006; Barnes and Raymond, 2009). Cultivation practices such as liming, fertilization, and irrigation affect the soil solution chemistry in agricultural systems, and changes in the vegetation density increase the soil partial pressure of $\mathrm{CO}_{2}, p \mathrm{CO}_{2}$ (Amundson and Davidson, 1990; Lee, 1997). Understanding the mechanisms by which agriculture changes $\mathrm{C}$ cycling is important for developing viable strategies for mitigating climate change (Lal, 2008), for example, the accelerated weathering of minerals that promotes the downward transport of DIC from terrestrial ecosystems (Andrews and Schlesinger, 2001; Karberg et al., 2005).

Liming of soils in agriculture using $\mathrm{Ca}, \mathrm{Mg}$-carbonates may be considered as anthropogenically facilitated weathering of carbonate that can sequester $\mathrm{CO}_{2}$ (Oh and Raymond, 2006). In the absence of other sources of protons, weathering of one mole of carbonate results in two moles of alkalinity for each mole of $\mathrm{CO}_{2(\mathrm{~g})}$ taken up (Eq. [1-2]).

$$
\begin{aligned}
& \mathrm{CO}_{2(\mathrm{~g})}+\mathrm{H}_{2} \mathrm{O} \leftrightarrow \mathrm{H}_{2} \mathrm{CO}_{3}{ }^{*} \leftrightarrow \mathrm{HCO}_{3}^{-}+\mathrm{H}^{+} \leftrightarrow \mathrm{CO}_{3}^{2-}+2 \mathrm{H}^{+} \\
& \mathrm{CaCO}_{3}+\mathrm{H}_{2} \mathrm{CO}_{3}{ }^{*} \leftrightarrow \mathrm{Ca}^{2+}+2 \mathrm{HCO}_{3}^{-}
\end{aligned}
$$


where $\mathrm{H}_{2} \mathrm{CO}_{3}{ }^{*}=\mathrm{CO}_{2(\mathrm{aq})}+\mathrm{H}_{2} \mathrm{CO}_{3}$. In contrast, the dissolution of $\mathrm{CO}_{2(\mathrm{~g})}$ into water produces nil mole alkalinity but one mole of $\mathrm{H}_{2} \mathrm{CO}_{3}{ }^{*}$ for each mole $\mathrm{CO}_{2(\mathrm{~g})}$ (Eq. [1]).

Recently, researchers have identified portlandite, $\mathrm{Ca}(\mathrm{OH})_{2}$, weathering (Eq. [3]) and silicate weathering by plant root-derived $\mathrm{CO}_{2(\mathrm{~g})}$ as a sink for atmospheric $\mathrm{CO}_{2(\mathrm{~g})}$ in urban and mine tailing soils of neutral to high pH (7-12) (Renforth et al., 2009; Wilson et al., 2011). Additional sequestration of $\mathrm{CO}_{2}$ has been postulated to occur when the weathering products remain dissolved (Manning and Renforth, 2013) (e.g., Eq. [2]).

$\mathrm{Ca}(\mathrm{OH})_{2}+\mathrm{H}_{2} \mathrm{CO}_{3}{ }^{*} \leftrightarrow \mathrm{CaCO}_{3}+2 \mathrm{H}_{2} \mathrm{O}$

Portlandite and silicates dominate the mineralogy of concrete. Concrete is commonly made by mixing aggregates of crushed rock and sand with water and Portland cement (Mehta and Monteiro, 2006). Hydrated ordinary Portland cement consists of 50 to $60 \%$ calcium silicate hydrates, 20 to $25 \%$ portlandite, and 15 to $20 \%$ calcium tri- and mono-sulfoaluminate hydrates. Depending on the degree of cement hydration, concrete may also contain some nonhydrated calcium silicates (Mehta and Monteiro, 2006). Concrete waste also contains calcium carbonate, $\mathrm{CaCO}_{3}$, from calcareous aggregates used in concrete production (Mehta and Monteiro, 2006) or as a consequence of the weathering of portlandite and nonhydrated calcium silicates by $\mathrm{CO}_{2}$ (concrete carbonation, e.g., Eq. [3-4]) (Claisse et al., 1999; Pade and Guimaraes, 2007).

$(\mathrm{CaO})_{2} \mathrm{SiO}_{2}+2 \mathrm{CO}_{2(\mathrm{~g})}+\mathrm{H}_{2} \mathrm{O} \rightarrow \mathrm{SiO}_{2} \cdot \mathrm{H}_{2} \mathrm{O}+2 \mathrm{CaCO}_{3}$

The fate of calcareous amendments to agricultural soils is controlled by several processes other than carbonic acid weathering. These include atmospheric acid deposition and acid generation by nitrification of ammonia-based fertilizers, which can cause neutralization or degassing of the bicarbonate formed by Reactions [1] and [2]. This will change lime application from being a $\mathrm{CO}_{2}$ sink into being $\mathrm{CO}_{2}$ neutral or even a source of $\mathrm{CO}_{2}$ to the atmosphere (West and McBride, 2005; Hamilton et al., 2007; Dumale et al., 2011; Tamir et al., 2011) and may neutralize the $\mathrm{CO}_{2}$ sink effect of amending soils with concrete waste.

We have investigated how the weathering of lime and CCW by the high $p \mathrm{CO}_{2}$ in the root zone of barley affects $\mathrm{C}$ cycling in the vadose zone. On the basis of previous studies (Oh and Raymond, 2006; Hamilton et al., 2007; Barnes and Raymond, 2009; Renforth, 2011), it was hypothesized that lime and CCW amendment would increase the DIC leaching to aquifers and/or store inorganic C as carbonate minerals if nitrate was the dominant $\mathrm{N}$ fertilizer.

\section{Materials and Methods}

\section{Construction and Maintenance of Mesocosms}

Soil was collected from the A and C horizons of cropped podzol soil developed on alluvial sand and packed into six mesocosm columns (20-cm diam., 85-cm height) above a bottom plate with an embedded filter disc (Thaysen et al., 2014a). The A and C horizons were located between 0 and 30 , and 30 and $78 \mathrm{~cm}$ depth from the mesocosm soil surface, respectively. The upper $15 \mathrm{~cm}$ of the A horizon soil in two replicate mesocosms were amended with either of 9.6 or $21.2 \mathrm{~kg} \mathrm{~m}^{-2}$ of ground CCW (particle size $<2$ $\mathrm{mm}$ ), corresponding to concrete levels in the soil of 4.7 and $10.5 \%$, respectively. These treatments will be referred to as the low and high CCW treatments. The applied CCW was collected from a construction waste site in Copenhagen, Denmark. Types of aggregate and cement in the CCW were unknown. The $\mathrm{pH}$ after CCW additions to the $\mathrm{A}$ horizon soil was $\sim 7$ and 8 for the low and high CCW treatments, respectively, as estimated from CCW additions to soil in Falcon tubes (BD Biosciences). Two mesocosms were amended with $1 \mathrm{~kg} \mathrm{~m}^{-2} \mathrm{CaCO}_{3}$ in the upper $15 \mathrm{~cm}(0-0.5 \mathrm{~mm}$, $98.3 \% \mathrm{CaCO}_{3}$, Faxe Kalk), aiming at a soil $\mathrm{pH}$ of 8 . The background $\mathrm{pH}$ of the A horizon soil varied between 5.4 and 6.3.

Mesocosms were planted with barley (Hordeum vulgare L. cv. Anakin) and maintained and irrigated with a 50\% strength Hoagland nutrient solution containing $8 \mathrm{mM} \mathrm{NO}_{3}{ }^{-}$and $0.5 \mathrm{mM}$ $\mathrm{NH}_{4}{ }^{+}$, as described in Thaysen et al. (2014b). The experiment was terminated $78 \mathrm{~d}$ after sowing. Two barley mesocosms from a previous experiment (Thaysen et al., 2014b) without any soil amendment served as controls.

\section{Sampling and Calculations $\mathrm{CO}_{2}$ Fluxes}

Ecosystem respiration (ER, the sum of the $\mathrm{CO}_{2(\mathrm{~g})}$ flux from the soil, $R_{\mathrm{s}}$, and the plant canopy) and net ecosystem exchange (NEE) were measured at regular intervals according to procedures in Thaysen et al. (2014a).

Soil $p \mathrm{CO}_{2}$ and soil water alkalinity were measured weekly at seven depths in the mesocosms, and soil temperature and moisture were logged at 10-min intervals as described in Thaysen et al. (2014a). Inorganic carbon speciation in the aqueous phase was calculated from $p \mathrm{CO}_{2}$, alkalinity, and temperature measurements using PHREEQC (Parkhurst and Appelo, 2011). When low $p \mathrm{CO}_{2}$ was measured at the mesocosm bottom due to high applied suction (i.e., low total pressure) under waterlogging, the $p \mathrm{CO}_{2}$ value was obtained from the next sampler above (Thaysen et al., 2014a). The DIC percolation was estimated from the calculated concentration of DIC, [DIC], at the mesocosm bottom and the drainage flux. 


\section{Mineral Equilibria}

Soil water samples from the end of the experiment (Days 71 and 72 for controls and amended mesocosms, respectively) and effluent samples from Days 28 (start) and 76 (end) were acidified to $\mathrm{pH} \sim 2$ (using $45 \% \mathrm{HNO}_{3}$, Sigma-Aldrich). Cation analysis and subsequent calculation of mineral saturation indices were done as described in Thaysen et al. (2014b).

\section{Plant Biomass and Root Length}

At the end of the experiment ( $78 \mathrm{~d}$ ), the aboveground biomass was harvested, oven-dried at $60^{\circ} \mathrm{C}$ for $2 \mathrm{~d}$, and weighed. For analyses of the total root mass, root distribution, and root length, the mesocosms were divided into six depth increments: $0-10,10-20$, $20-30,30-45,45-60$, and $60-80 \mathrm{~cm}$. Roots in each section were separated from the soil by wet sieving $(600 \mu \mathrm{m})$ and weighed; a 0.5 - to 1.0-g subsample from each section was stored in $50 \% \mathrm{EtOH}$. The rest was dried and weighed.

The EtOH-preserved root samples were evenly spread on a transparent tray $(17.5$ by $23.9 \mathrm{~cm})$ and scanned using a high resolution Epson Perfection V700 PHOTO (modelJ1221A, Seiko Epson Corp.). Root lengths were calculated from the generated images by means of the 2009b version of the Win-Rhizo software (Regent Instruments Inc.). The ratio between subsample and total fresh weight was used to calculate the root length in each section. Plant biomass was reported on area basis $\left(\mathrm{g} \mathrm{m}^{-2}\right)$.

\section{Soil Mineral Buffer Content}

At the end of the experiment, soil samples of $100 \mathrm{~cm}^{3}$ were taken from each of the three depth increments of the A horizon (see above) and homogenized using the cone and quarter technique (Raab et al., 1990). The mineral buffer content, consisting mainly of calcium carbonate and, in the case of CCW-amended mesocosms also of portlandite, was determined for five replicate samples of $\sim 2 \mathrm{~g}$ of crushed soil $(<125 \mu \mathrm{m})$. Samples were acidified with $50 \mathrm{~mL} 2.8 \mathrm{M} \mathrm{HCl}$ and heated to $160^{\circ} \mathrm{C}$ to dissolve solid carbonate/portlandite, then washed with milli- $\mathrm{Q}$ water to near-neutral $\mathrm{pH}$, and freeze-dried. The mineral buffer content was calculated from the difference in sample mass before and after acidification (USDA, 1954). The CCW was subjected to the same analysis as the soil samples.

\section{Statistical Analysis}

The correlation between cumulative drainage and cumulative DIC percolation was analyzed by linear regression ( $\mathrm{R}$ software, version 2.12.0). Treatment means for soil carbonate content, root mass density, and root length density were compared by the Welch $t$ test (Welch, 1947). Differences in the slopes of the ER and NEE vs. time and the cumulative DIC percolation flux vs. cumulative drainage, respectively, were analyzed using a Tukey HSD test (Tukey, 1953).

\section{Modeling}

Experimental results from limed mesocosm 1 and low CCWamended mesocosm 1 were modeled for Days 20 through 61 through implementation of a modified version of SOILCO2 (Šimůnek and Suarez, 1993) into the HP1 module of the Hydrus 1D software (Šimůnek et al., 2006; Jacques et al., 2008). A thorough description of the conceptual and mathematical model is given in the supplementary information. Model results for water and $\mathrm{CO}_{2}$ fluxes in the control mesocosms are given in Thaysen et al. (2014b).

Lime- and CCW-amended mesocosms were modeled in the same manner as control mesocosms with regard to discretization, evapotranspiration, heat transport, tortuosity, and external boundary conditions (see Thaysen et al., 2014b for detailed information). The initial exchanger compositions, as measured from soil extractions, were $\left(\mathrm{mg} \mathrm{kg}^{-1}\right) 40.28 \mathrm{Ca}^{2+}, 2.31 \mathrm{Mg}^{2+}, 8.99 \mathrm{~K}^{+}, 3.22 \mathrm{Na}^{+}, 0.16$ $\mathrm{Al}^{3+}$ and $2.00 \mathrm{Ca}^{2+}, 0.23 \mathrm{Mg}^{2+}, 7.82 \mathrm{~K}^{+}, 0.30 \mathrm{Na}^{+}, 0.06 \mathrm{Al}^{3+}$ for the A and C horizon, respectively (Thaysen et al., 2014b). Soil hydraulic parameters for the van Genuchten-Maulum model with $m=1-1 / n$ were obtained from inverse modeling of the water flow using Hydrus 1D (Šimůnek et al., 2013) and a global stochastic optimization algorithm (Vrugt et al., 2009). Soil hydraulic parameters for limed and CCW-amended mesocosms 1 were similar to the controls, except for the saturated pore volume, which was 0.39 in amended mesocosms instead of 0.45 for the controls. The optimum $\mathrm{CO}_{2}$ production rates in amended mesocosms were scaled to account for the difference in the saturated pore volumes. The reasoning is that the $p \mathrm{CO}_{2}$ and the $R_{\mathrm{s}}$ depend on the air-filled pore volume and that the air-filled pore volume in general decreases at lower saturated pore volume but equal irrigation amounts. The optimum $\mathrm{CO}_{2}$ production rates in amended mesocosms were set at $0.7 \mu \mathrm{mol} \mathrm{m}^{-2} \mathrm{~s}^{-1} \mathrm{~g}^{-1}$ root dry weight (DW) as obtained from multiplication of the optimum $\mathrm{CO}_{2}$ production rate in control mesocosms of $0.8 \mu \mathrm{mol} \mathrm{m}^{-2} \mathrm{~s}^{-1} \mathrm{~g}^{-1}$ root DW with the ratio of the saturated pore volumes. The depth distribution of microbial respiration in limed and CCW-amended mesocosms was scaled with an a parameter of $0.0015 \mathrm{~m}^{-1}$ as for the controls.

Due to a similar plant biomass in low CCW, limed, and control mesocosms (Table 1), the soil respiration was modeled in the same way by linking the optimum $\mathrm{CO}_{2}$ production rate to a linear root mass increase with time that was calculated from the observed root growth data. Based on the linear root mass increase, initial root masses in mesocosm 1 of the limed and mesocosm 1 of the low CCW treatment on Day 20 (Day 0 of simulation) were calculated to 2.7 and $3.7 \mathrm{~g} \mathrm{DW}$, respectively, with respective root growth rates of 0.18 and $0.26 \mathrm{~g} \mathrm{DW} \mathrm{d}^{-1}$. Estimates of the $R_{\mathrm{s}}$ (soil $\mathrm{CO}_{2}$ efflux due to respiration by roots and microorganisms) resulted from correction of the measured ER (canopy respiration $+R_{\mathrm{s}}$ ) by a factor of 0.67 , which assumed that (i) canopy respiration was roughly $50 \%$ of the total plant respiration (Poorter et al., 1990; Loveys et al., 2002) and (ii) root respiration accounted for $50 \%$ of the total 
Table 1. Aboveground biomass at harvest $(\mathrm{AB})$, increase per day $(\triangle \mathrm{AB})$, and aboveground biomass density (ABD), root dry weight, and root length throughout depth in mesocosms in the low and high crushed concrete waste (CCW), limed, and control treatments.

\begin{tabular}{|c|c|c|c|c|c|}
\hline Parameter & Depth, cm & Low CCW & High CCW & Lime & Control \\
\hline $\mathrm{AB} \pm \mathrm{SE}(\mathrm{g} \mathrm{DW}) \neq$ & - & $59.1 \pm 6.1$ & $76.6 \pm 0.2$ & $57.9 \pm 7.9$ & $82.7 \pm 2.7 \dagger$ \\
\hline$\Delta \mathrm{AB} \pm \mathrm{SE}\left(\mathrm{g} \mathrm{DW} \mathrm{d}^{-1}\right)$ & - & $0.84 \pm 0.06$ & $1.09 \pm 0.002$ & $0.83 \pm 0.08$ & $0.84 \pm 0.02$ \\
\hline \multirow[t]{4}{*}{ Root biomass ( $\mathrm{g} \mathrm{DW} \mathrm{m}^{-2}$ ) } & $0-10$ & $321.0 \pm 40.6$ & $284.6 \pm 27.9$ & $295.4 \pm 4.1$ & NAS \\
\hline & $10-20$ & $145.1 \pm 11.8$ & $123.3 \pm 11.1$ & $123.8 \pm 36.3$ & NA \\
\hline & $45-60$ & $25.0 \pm 6.7$ & $10.6 \pm 0.7$ & $14.6 \pm 10.4$ & NA \\
\hline & $60-80$ & $4.4 \pm 0.18$ & $<0.01$ & $<0.01-1.76$ & NA \\
\hline \multirow[t]{2}{*}{ Root length $\pm \mathrm{SE}\left(\mathrm{Km} \mathrm{m}^{-2}\right)$} & $0-10$ & $31.6 \pm 4.7$ & $19.7 \pm 1.1$ & $30.1 \pm 3.9$ & NA \\
\hline & $10-20$ & $14.9 \pm 1.0$ & $17.2 \pm 0.5$ & $21.3 \pm 1.5$ & NA \\
\hline
\end{tabular}

† Control mesocosms were harvested $29 \mathrm{~d}$ later than amended mesocosms and the $\mathrm{AB}$ can hence only be compared on a daily basis.

キ DW, dry weight.

$\S \mathrm{NA}$, not available.

$R_{\mathrm{s}}$ (variation from 10 to $90 \%$; Hanson et al., 2000). Root nutrient uptake was modeled using average nutrient uptake rates per gram plant DW (Marschner, 1995), which were reculated to the influx per gram of root DW and multiplied by the time-dependent root mass (Thaysen et al., 2014b).

\section{Results}

\section{Plant Growth}

The root biomass varied between 250 and $350 \mathrm{~g} \mathrm{~m}^{-2}$ in the upper $10 \mathrm{~cm}$ of the mesocosms and decreased exponentially with depth (Table 1). Roughly $90 \%$ of the total root biomass was located in the A horizon, and only few roots were present beyond $0.6 \mathrm{~m}$ depth. The root length was highest in the A horizon (up to $32 \mathrm{~km} \mathrm{~m}^{-2}$ in the upper $10 \mathrm{~cm}$ ) and decreased one order of magnitude in the $\mathrm{C}$ horizon (Table 1). Root mass and root lengths showed no significant treatment effects $(p>0.84)$.

The total aboveground biomass could not be directly compared between controls and amended mesocosms due to different harvest times. However, the daily growth rate of the aboveground biomass, assuming a linear increase with time, was higher in the high CCW amendment compared to other treatments (Table 1).

\section{Temporal Variation of Inorganic Carbon}

Inorganic $\mathrm{C}$, distributed between gaseous and aqueous phase species (i.e., $\mathrm{CO}_{2(\mathrm{~g})}$ and DIC), showed a strong increase with time in all mesocosms (Fig. 1). The predominant inorganic $\mathrm{C}$ species was in all cases $\mathrm{CO}_{2(\mathrm{~g})}$. The $[\mathrm{DIC}]$ in the $\mathrm{A}$ horizon $(0-30 \mathrm{~cm})$ increased in the order: control $<$ lime $<$ CCW. Bicarbonate was the dominant DIC species in the $\mathrm{A}$ horizon. In the $\mathrm{C}$ horizon (30-78 $\mathrm{cm}$ ), with $\mathrm{pH}<6, \mathrm{H}_{2} \mathrm{CO}_{3}{ }^{*}$ dominated. A downward moving front of high [DIC] was observed in the lime and CCW treatments, with a steeper front in CCW-amended mesocosms than in the limed ones.

\section{Gaseous and Dissolved $\mathrm{CO}_{2}$ Emissions}

The ER, the sum of the $\mathrm{CO}_{2(\mathrm{~g})}$ flux from the soil and the plant canopy, increased with plant age (Fig. 2a). The ER decreased in the order: high CCW > low CCW > lime > control, with magnitudes on the last day of the experiment of $90 \pm 1.4,77 \pm 0.9,64 \pm$ 1.7 , and $45 \pm 0.6 \mu \mathrm{mol} \mathrm{m}^{-2} \mathrm{~s}^{-1}$, respectively. Hence, the peak ER was increased by 100,71 , and $42 \%$ in the high CCW, low CCW, and lime treatments, respectively, as compared to the controls $(p<$ $0.01)$. The difference between the ER of limed and CCW-amended mesocosms was not significant.

The NEE (net ecosystem exchange $=$ the gross primary production minus the $\mathrm{ER}$, i.e., the $\mathrm{CO}_{2(\mathrm{~g})}$ flux in the light period) became more negative (i.e., $\mathrm{CO}_{2(\mathrm{~g})}$ uptake by the ecosystem increased) with plant age up to Day 49 and declined thereafter (Fig. 2b). There were no treatment differences in the $\operatorname{NEE}(p \geq 0.75)$.

The DIC percolation flux was more than one order of magnitude lower than the ER flux (Fig. 2c). The cumulative DIC percolation was $971 \pm 4,844 \pm 9,749 \pm 5$, and $382 \pm 5 \mathrm{mmol} \mathrm{C} \mathrm{m}^{-2}$ for the low CCW, high CCW, lime, and control treatments, respectively 

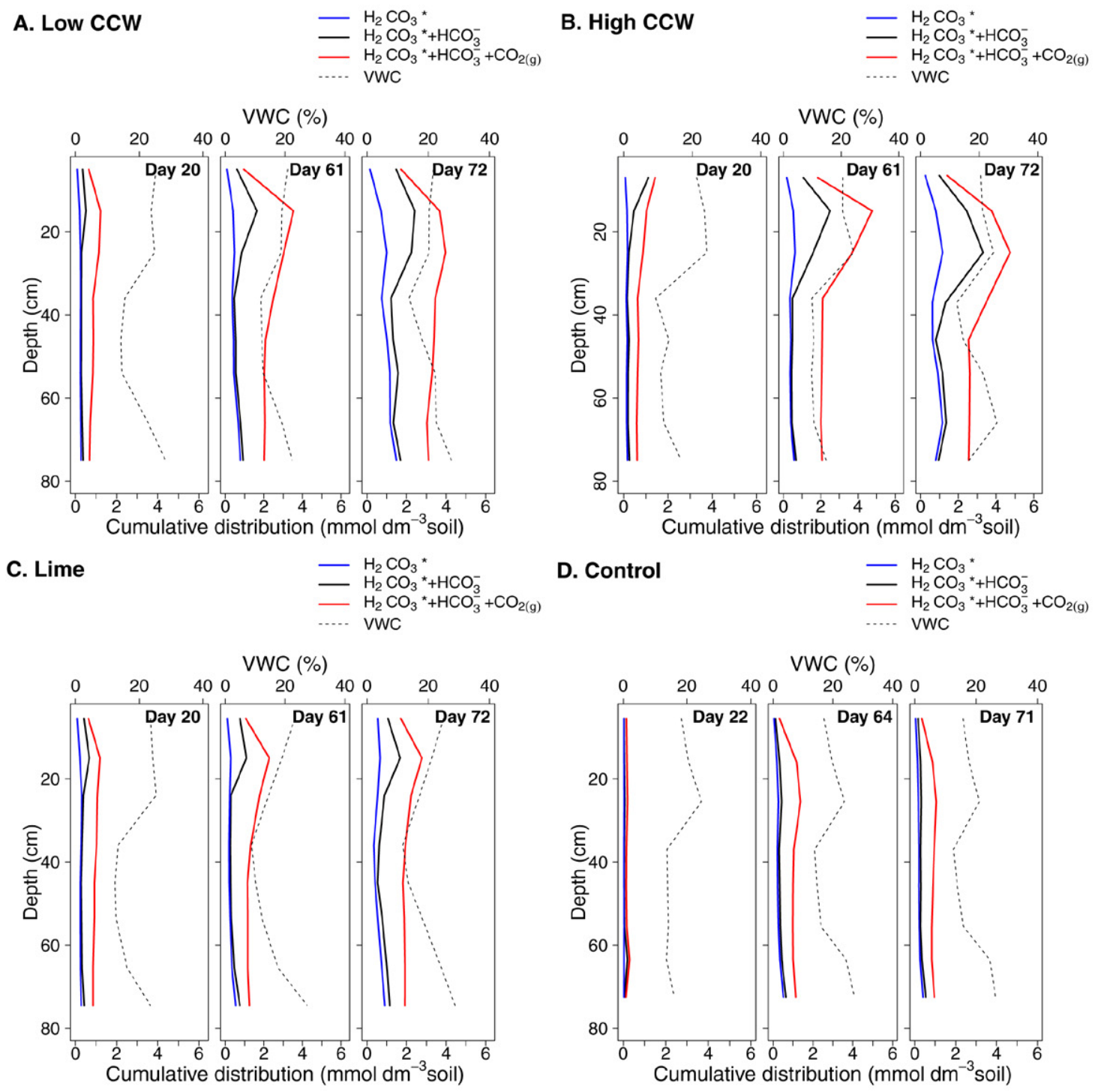

Fig. 1. Distribution of inorganic $\mathrm{C}$ between $\mathrm{CO}_{2}(\mathrm{~g})$ and DIC species and volumetric water content (VWC) and at the start of the measurement period (Day 20), near the end (Day 61) and at the end (Day 72) in (A) low crushed concrete waste (CCW)-amended, (B) high CCW-amended, (C) limed, and (D) control mesocosms. Shown are the means for each treatment. Controls were measured on slightly differing days than amended mesocosms. The concentration of $\mathrm{CO}_{3}{ }^{2-}$ was negligible compared to the other species and is therefore not shown.

(Fig. 2d), and was highly correlated with cumulative drainage ( $p<$ $\left.2 \times 10^{-16}\right)$. The cumulative drainage from the mesocosms varied from $108 \mathrm{~mm}$ for mesocosm 2 of the high CCW treatment to 186 $\mathrm{mm}$ for the limed mesocosm 1 (Fig. 2d). The cumulative drainage corresponded to 0.9 to 1.1 water-filled pore volumes for amended mesocosms and 1.3 to 1.5 for the controls. The average [DIC] in the drainage decreased in the order: low $\mathrm{CCW} \approx$ high $\mathrm{CCW}>$ lime $>$ control, and was $5.9 \pm 0.3,5.7 \pm 0.1,4.7 \pm 0.2$, and $2.5 \pm 0.1 \mathrm{mmol}$ $\mathrm{L}^{-1}$, respectively, with $p \leq 0.018$ for differences between the control and amended mesocosms and $p \geq 0.11$ for differences between the amendments. The DIC percolation was increased by 90 to 120 , 150 to 160 , and 140 to $170 \%$ for the lime, low CCW, and high CCW treatments, respectively, as compared to the controls.

\section{Aluminum Hydroxide, Calcite Saturation, and $\mathrm{CO}_{2}$ Source-Sink Relations}

Because of the $\mathrm{pH}$-dependent solubility of inorganic $\mathrm{C}$ species (Eq. [1]), the [DIC] is largely influenced by processes that change the soil alkalinity, such as the weathering or precipitation of soil minerals (Appelo and Postma, 2005; Walmsley et al., 2011). A screening of possible mineral controls on the [DIC] in the mesocosms showed slight supersaturation of the pore water from Days 71 to 72 for amorphous aluminum hydroxide, $\mathrm{Al}(\mathrm{OH})_{3(\mathrm{a})}$, in both soil horizons of all treatments (Fig. 3a and 3b, Eq. [5]), indicating precipitation of this mineral.

$$
\mathrm{Al}(\mathrm{OH})_{3(\mathrm{a})}+3 \mathrm{H}^{+} \leftrightarrow \mathrm{Al}^{3+}+3 \mathrm{H}_{2} \mathrm{O}
$$


The A horizon samples of all CCW-amended mesocosms were in equilibrium with calcite, $\mathrm{CaCO}_{3}$ (Fig. 3c, Eq. [6]), while C horizon samples were mostly subsaturated for calcite (Fig. 3d).

$$
\mathrm{CaCO}_{3} \leftrightarrow \mathrm{Ca}^{2+}+\mathrm{CO}_{3}^{2-}
$$

In limed and control mesocosms, the majority of the A and $\mathrm{C}$ horizon samples were subsaturated for calcite (Fig. $3 \mathrm{c}$ and $3 \mathrm{~d}$ ), indicating that lime dissolved primarily before Day 71.

The effect of lime addition can be tracked from the ratio of alkalinity to the sum of $\mathrm{Ca}$ and $\mathrm{Mg}$ ions, $\Sigma_{\mathrm{Ca}, \mathrm{Mg}}$ (Eq. [2]) (Hamilton, Kurzman et al., 2007). Magnesium is included because lime is not pure calcite but $\mathrm{Ca}_{1-x} \mathrm{Mg}_{x} \mathrm{CO}_{3}$ typically with $0.05<x$ $<0.15$. If the ratio is $2: 1\left(\mathrm{mmol} \mathrm{L}^{-1}: \mathrm{mmol}\right.$ $\mathrm{L}^{-1}$ ), then the dissolution of lime provides an ideal sink for $\mathrm{CO}_{2(\mathrm{~g})}$. If the ratio is $1: 1$ then lime is neither sink nor source, and if the ratio is $<1: 1$ it is a $\mathrm{CO}_{2(\mathrm{~g})}$ source. Figure $3 \mathrm{e}$ and $3 \mathrm{f}$ show the ratio of alkalinity to $\Sigma_{\mathrm{Ca}, \mathrm{Mg}}$ in A and $\mathrm{C}$ horizon soil solutions, respectively, of limed mesocosms. In all A horizon and the majority of $\mathrm{C}$ horizon samples the alkalinity to $\Sigma_{\mathrm{Ca}, \mathrm{Mg}}$ ratio was 2:1 or higher, and lime dissolution was hence a sink for atmospheric $\mathrm{CO}_{2}$. Four $\mathrm{C}$ horizon samples had a ratio close to or lower than 1:1, indicating dissolution of lime by acids other than carbonic acid or removal of $\mathrm{Ca}$ by ion exchange.

Low and similar concentrations of trace elements in the effluent from all mesocosms were observed (see Supplemental Material, Table S1).

\section{Soil Mineral Buffer Content}

Additional insight into whether calcareous amendments provide a $\mathrm{CO}_{2}$ sink or source may be gained from an investigation of the soil mineral buffer content. At the end of the experiment, the soil mineral buffer content of the upper $10 \mathrm{~cm}$ in low CCW and limed mesocosms was not different from the controls $(p \geq 0.37)$, but the high CCW treatment had an elevated mineral buffer content $(p<$ 0.001) (Fig. 4A). Treatment effects were not apparent when considering the mineral buffer contents of the total A horizon (0-30 cm) (Fig. 4B).

The mineral buffer contents were $4.2 \%$ in the control mesocosms and $22.2 \pm 0.1 \%$ in the CCW material. Based on this, mineral buffer contents at the beginning of the experiment after amendment of the upper $15 \mathrm{~cm}$ of low CCW, high CCW, and limed mesocosms were calculated as $5.2,6.5$, and $4.7 \%$, respectively. The mineral buffer content measured at the end of the experiment was lower than the calculated initial content in the application zone in all amended mesocosms (Fig. 4A), equaling equivalent losses of the mineral buffer of 13 to 21 and 14 to $16 \%$ of the applied amount in CCW and lime amended mesocosms, respectively. Also in the total A horizon, final mineral buffer contents were lower than initial ones (Fig. 4B). This indicates that the applied mineral buffer was dissolved and subsequently degassed or transported downward (see Discussion).

\section{Modeling}

To simulate the biological, chemical, and physical processes during plant growth, results from limed mesocosm 1 and low CCWamended mesocosm 1 were modeled using the approach described in the Materials and Methods section. In control mesocosms, the carbonic acid production by the increasing $p \mathrm{CO}_{2}$ during barley growth was buffered by a net hydroxide ion excretion from the roots during nutrient assimilation which caused an alkalinity increase of $\sim 1$ meq $L^{-1}$ during the experimental period (Thaysen et al., 2014b). Simulations with aluminum hydroxide buffering did 
not provide an equally satisfactory description of the observations as simulations using root nutrient uptake.

Aluminum hydroxide buffering was also expected to be of minor importance in limed and CCW-amended mesocosms, as $\left[\mathrm{Al}^{3+}\right]$ was assumed to be relatively low in comparison to $\left[\mathrm{Ca}^{2+}\right]$ and $\left[\mathrm{CO}_{3}{ }^{2-}\right]$ or $\left[\mathrm{Ca}^{2+}\right]$ and $\left[\mathrm{OH}^{-}\right]$ released by dissolution of calcite or portlandite, respectively. In line with this, the measured alkalinity and Ca values in lime- and CCWamended mesocosms showed similar peaks in the A horizon (Fig. 5b and 5f, Supplement Fig. S8B and S8F), suggesting buffering by calcite. The effects of the two buffering mechanisms were investigated by running two scenarios: scenario 1 had aluminum hydroxide buffering and cation exchange throughout the mesocosms, while scenario 2 coupled calcite equilibrium with cation exchange. Neither of the two scenarios provided a perfect fit to the measured data, but scenario 1 generally performed better than scenario 2 (Fig. 5, Supplement Fig. S7-S9 and Text T1). Here we only present scenario 1 for the limed mesocosm since the uncertainties in the simulation were smaller compared to CCW-amended mesocosms, where the chemical composition of the CCW was unknown. In scenario 1 for the limed mesocosm, the saturation index of $\mathrm{Al}(\mathrm{OH})_{3(\mathrm{a})}$ was set to 0.7 at all depths, as measured on Day 72 (Fig. 3a), using an abundance of $1 \mathrm{mmol} \mathrm{Al}(\mathrm{OH})_{3(\mathrm{a})} \mathrm{dm}^{-3}$ soil. Modeling used a kinetic lime dissolution rate of $0.7 \times 10^{-9} \mathrm{~mol} \mathrm{dm}^{-3}$ soil s$^{-1}$ as fitted to the measured alkalinity increase.

\section{Model Evaluation}

The measured evolution of the $\mathrm{pCO}_{2}$ was generally well described (Fig. 5a). Lowering the total pressure at the mesocosm bottoms by sampling suction caused a decrease in the $p \mathrm{CO}_{2}$ (Fig. 5a) that was most pronounced when waterlogging (Supplement Fig. S2) was highest (Thaysen et al., 2014a). The simulated evolution of alkalinity and $\mathrm{pH}$ over time was satisfactory in terms of magnitude and peak depth, but the steep decline in the $\mathrm{C}$ horizon alkalinity and $\mathrm{pH}$ could not be captured (Fig. 5b,c). Evolution of the $R_{\mathrm{s}}$ was simulated well up to Day 50 but was underestimated thereafter (Fig. 5i). Due to the dependency of the $p \mathrm{CO}_{2}$ and the $R_{\mathrm{s}}$ on the volumetric water content (VWC), a correct description of the VWC, especially near the soil surface, was crucial. The VWC and the drainage flux were generally well described, but the topsoil VWC was slightly overpredicted toward the end of the experiment (Supplement Fig. S2-S3).
A horizon
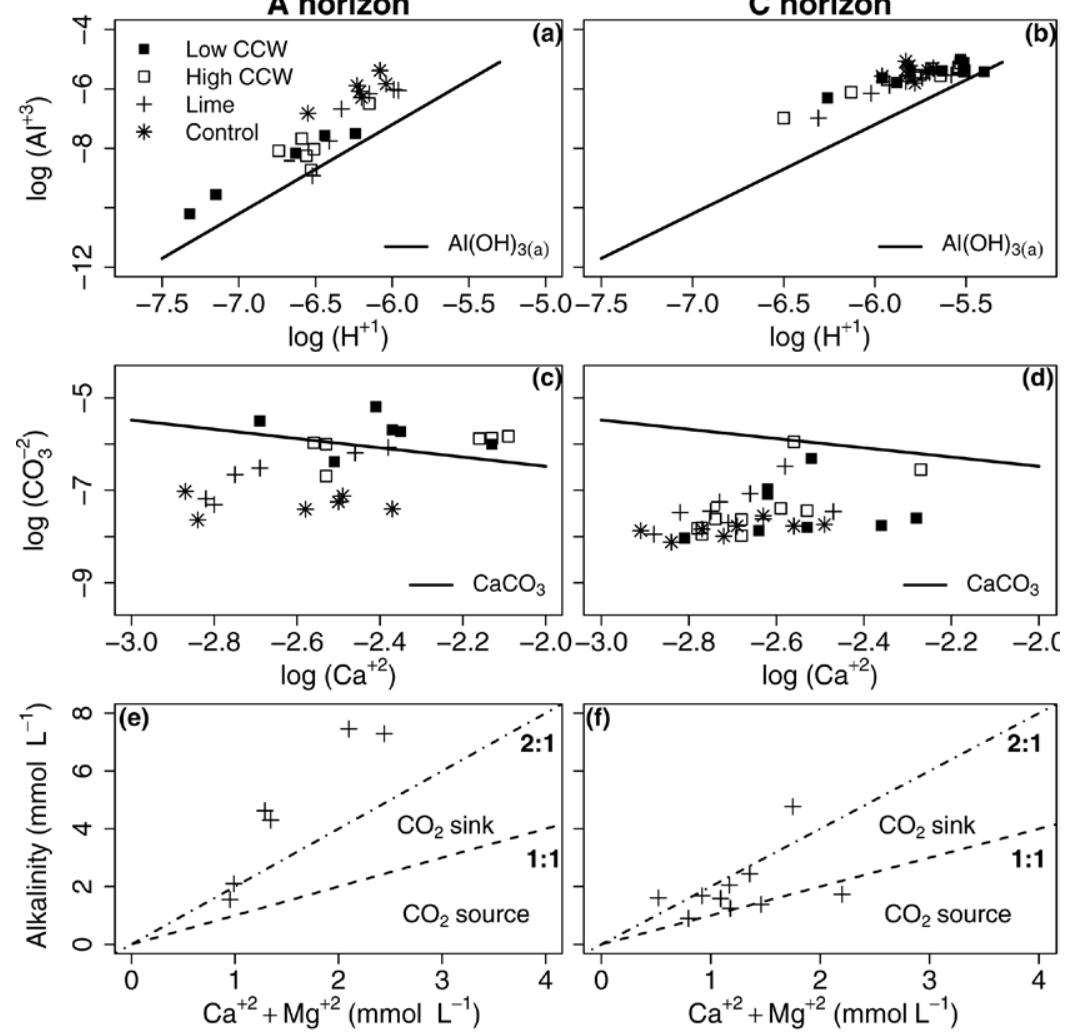

Fig. 3. (a, b) Log activities of $\mathrm{Al}^{3+}$ vs. $\mathrm{H}^{+}$in the $\mathrm{A}$ and $\mathrm{C}$ horizon of the mesocosms as compared to $\mathrm{Al}(\mathrm{OH})_{3(\mathrm{a})}$ equilibrium (see lines in (a) and (b), respectively) and (c, d) log activities of $\mathrm{CO}_{3}{ }^{2+}$ vs. $\mathrm{Ca}^{2+}$ as compared to $\mathrm{CaCO}_{3}$ equilibrium. (e, f) Evidence for carbonate mineral dissolution by carbonic acid in limed mesocosms. If the ratio is $2: 1(\mathrm{mmol}$ $\left.\mathrm{L}^{-1} \mathrm{mmol} \mathrm{L}{ }^{-1}\right)$, then the dissolution of lime provides an ideal sink for $\mathrm{CO}_{2}(\mathrm{~g})$. If the ratio is $1: 1$, then lime is neither sink nor source, and if the ratio is $<1: 1$ it is a $\mathrm{CO}_{2(\mathrm{~g})}$ source. Samples were taken on Day 72 for amended mesocosms and on Day 71 for controls.

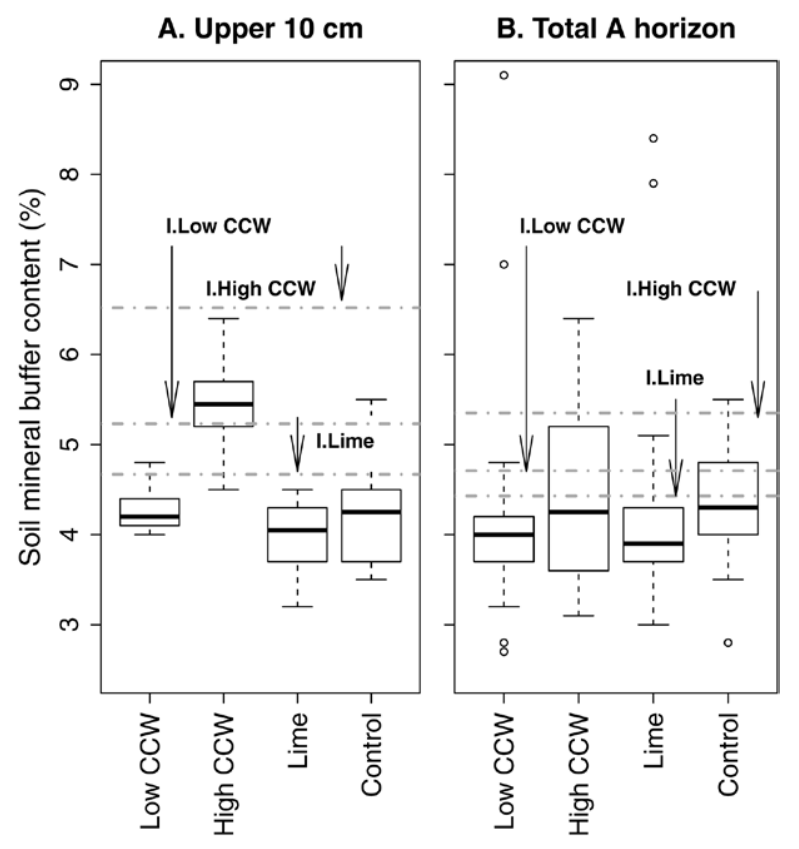

Fig. 4. Initial (dashed lines) and final (boxes) soil mineral buffer contents (see methodology) in (A) the upper $10 \mathrm{~cm}$ of mesocosms and (B) in the total A horizon $(0-30 \mathrm{~cm})$. 
Simulation of $\mathrm{CO}_{2}$ fluxes in Lime Mes. 1 (Scenario 1)
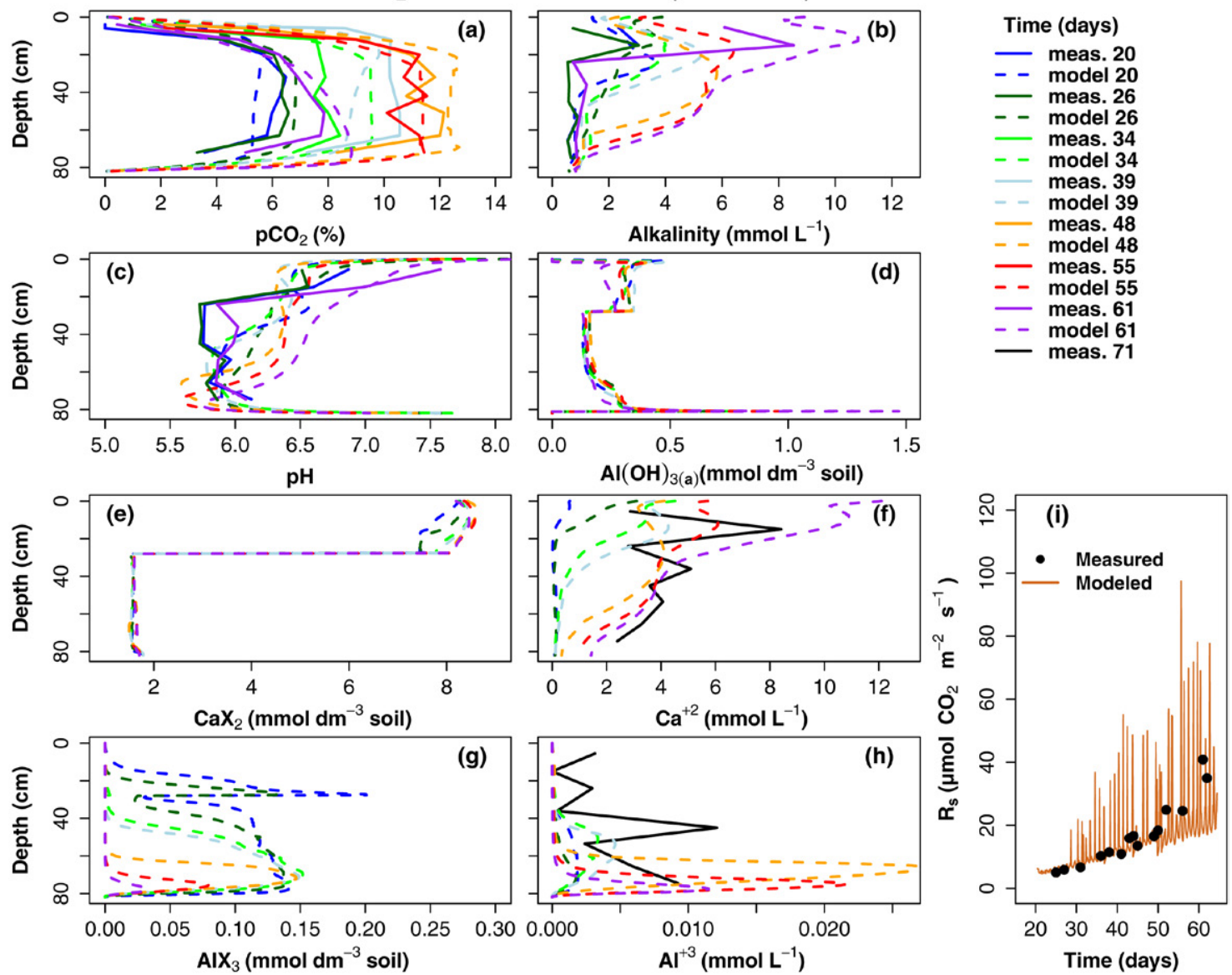

Fig. 5. (a) Measured (full lines) and modeled (dashed lines) temporal variation of soil air $p \mathrm{CO}_{2}$, (b) alkalinity, (c) $\mathrm{pH},(\mathrm{d})$ amount of $\mathrm{Al}(\mathrm{OH})_{3(\mathrm{a})}$ (e) $\mathrm{CaX}_{2}$, (f) $\mathrm{Ca}^{2+}$, (g) $\mathrm{AlX}_{3}$, and (h) $\mathrm{Al}^{3+}$ in limed mesocosm 1. (i) Measured (dots) and modeled (lines) $\mathrm{CO}_{2}$ efflux from the top of the mesocosm $\left(R_{\mathrm{s}}\right)$. Simulations include nutrient irrigation and root solute uptake, kinetic $\mathrm{CaCO}_{3}$ dissolution, and $\mathrm{Al}(\mathrm{OH})_{3 \text { (a) }}$ buffering throughout the soil profile $\left(\mathrm{SI}_{\mathrm{Al}(\mathrm{OH}) 3(\mathrm{a})}=0.7\right)$. Small fluctuations in the simulated $R_{\mathrm{s}}$ around the baseline arise from diurnal temperature variations. Large fluctuations are numerical noise caused by the fact that the numerical solution does not fully obey the von Neumann stability criteria (Šimůnek et al., 2006).

In addition to an alkalinity increase by a net hydroxide ion excretion during root nutrient assimilation (as described for control mesocosms above), calcite dissolution gradually increased the alkalinity in the A horizon (Fig. 5b). Evapotranspiration increased ion concentrations in the A horizon by a factor of $\sim 3$ to 3.5 (Supplement Fig. S4) (Thaysen et al., 2014b). Nutrient application by irrigation and calcite dissolution further led to high $\left[\mathrm{Ca}^{2+}\right]($ Fig. 5f) that triggered displacement of exchanger-bound $\mathrm{Al}$ (Fig. 5g and 5h, Eq. [7]), Na, K, and Mg.

$$
\frac{1}{3} \mathrm{Al} X_{3}+\frac{1}{2} \mathrm{Ca}^{2+} \leftrightarrow \frac{1}{3} \mathrm{Al}^{3+}+\frac{1}{2} \mathrm{Ca} X_{2}
$$

In the model, $\mathrm{Al}(\mathrm{OH})_{3(\mathrm{a})}$ was dissolved in the upper $\mathrm{A}$ horizon throughout the simulated time (Fig. 5d). Released Al from dissolving $\mathrm{Al}(\mathrm{OH})_{3(\mathrm{a})}$ and by $\mathrm{Ca}-\mathrm{Al}$ exchange (Eq. [7]) near the surface was precipitated in the lower A horizon and in the $\mathrm{C}$ horizon between Days 20 and 39 (Fig. 5d, Eq. [5]). The precipitation of $\mathrm{Al}(\mathrm{OH})_{3(\mathrm{a})}$ lead to proton release (Eq. [5]), which caused protonation of bicarbonate followed by the degassing to $\mathrm{CO}_{2}(\mathrm{~g})$ (Eq. [1]). The net precipitation of $\mathrm{Al}(\mathrm{OH})_{3(\mathrm{a})}$ caused a generally lower alkalinity in the $\mathrm{C}$ horizon than in the $\mathrm{A}$ horizon (Fig. 5b). Alkalinity consumption by $\mathrm{Al}(\mathrm{OH})_{3(\text { a) }}$ precipitation beyond the simulated was not possible, as Al was depleted (Fig. $5 \mathrm{~g}$ and $\mathrm{h}$ ). Measurements at Day 71 showed more dissolved Al than simulated around 30 and $50 \mathrm{~cm}$ depth, indicating that there may be additional ongoing processes in the mesocosms that are not included in the model.

\section{Discussion}

We have successfully quantified C dynamics in nonamended, limed, and CCW-amended planted mesocosms, representing the vadose zone of a cultivated podzol. The results showed that DIC percolation fluxes may be increased by 90 to 120 and 140 to $170 \%$ by lime and CCW amendment compared to nonamended soil, respectively, without compromising plant growth or groundwater quality. This at first indicates a large potential of CCW and lime amendment 
for increasing $\mathrm{CO}_{2}$ transport to groundwater. However, considering concurrent increases in the ER from amended mesocosms of more than one order of magnitude higher relative to increases in the DIC percolation flux turns lime and CCW amendment into $\mathrm{CO}_{2}$ sources to the atmosphere. In the following, our results are discussed with regard to the plant growth in mesocosms and possible causes for the elevated ER from amended mesocosms.

\section{Influence of Plant Growth on Gaseous $\mathrm{CO}_{2}$ Fluxes}

The high $\mathrm{CO}_{2(\mathrm{~g})}$ in control mesocosms (Fig. 1D) may be explained by the correlation between the magnitude of the root $\mathrm{CO}_{2}$ production and the amount of plant root matter (Schüßler et al., 2000) since the aboveground and root biomass were significantly higher in the mesocosms compared to field-grown cereals (Table 1). The aboveground biomass was approximately three to four times higher than under field conditions (Olesen et al., 2000; Lohila et al., 2003; Walmsley et al., 2011), but in accordance with reported values from barley grown in pots (Simojoki et al., 1991). The root mass in mesocosms was two to five times higher than in the field (Barraclough and Leigh, 1984; Xu and Juma, 1992; Malhi and Gill, 2002), and the root length was two to four times higher (Jakobsen and Nielsen, 1983; Barraclough and Leigh, 1984; Haberle et al., 1996) but also in the range of previously reported values for pot experiments (Marschner et al., 1991; Ravnskov and Jakobsen, 1995; Weligama et al., 2010). In addition, soil temperatures (Supplement, Fig. S1) were $\sim 3$ to $5^{\circ} \mathrm{C}$ higher than typical day- and night-time temperatures in the field (Denmark), also inducing a larger $\mathrm{CO}_{2}$ production rate (Amundson and Davidson, 1990; Bond-Lamberty and Thomson, 2010).

The average plant growth rate in low CCW and limed mesocosms was similar to the controls (Table 1). Hence, gross photosynthetic activity and respiration (i.e., biological $\mathrm{CO}_{2}$ production) can be expected to have been equal. In high CCW mesocosms, plant growth was higher than in the remaining treatments and this contributed to the elevated $\mathrm{CO}_{2(\mathrm{~g})}$ and ER (Fig. 1 and $2 \mathrm{~A}$, respectively), as was shown by Ahmad et al. (2013) for stimulating effects of lime on plant growth and ER.

\section{Source of Elevated $\mathrm{CO}_{2}$ Efflux to the Atmosphere and Missing Subsoil Inorganic Carbon}

Despite the flushing of about one water-filled pore volume, the front of high [DIC] did not reach the bottom of the amended mesocosms (Fig. 1A-1C). This is consistent with a consumption of alkalinity in the $\mathrm{C}$ horizon by reaction with soil acidity, leading to $\mathrm{C}$ transfer from the DIC pool to the gas phase and subsequent diffusive loss. Considering equal plant growth in control, limed and low CCW mesocosms, the higher $\mathrm{CO}_{2(\mathrm{~g})}$ and ER from amended mesocosms compared to the controls seems derived from a degassing of the $\mathrm{C}$ pool of carbonates contained in the amendments. In line with this, the alkalinity to $\Sigma_{\mathrm{Ca}, \mathrm{Mg}}$ ratios of the subsoils in limed mesocosms indicated lime dissolution by acids other than carbonic acid (or Ca exchange, Fig. 3f). A comparison between the soil losses of mineral buffer and increases in the ER strongly supports this hypothesis: The difference between the initial and the final mineral buffer contents in high CCW, low CCW, and limed mesocosms (Fig. 4A) equaled C losses of 17 to 27, 20, and 13 to $15 \mathrm{~mol} \mathrm{~m}^{-2}$ from the zone of application, respectively. Summation of the estimated $R_{\mathrm{s}}$ (see modeling methodology) over the experimental period, applying linear interpolation between ER measurements, results in increases in the $R_{\mathrm{s}}$ of 30 to 32,17 , and 11 to $16 \mathrm{~mol} \mathrm{C} \mathrm{m}{ }^{-2}$ for high CCW, low CCW, and limed mesocosms, respectively, relative to the controls. These figures show very good agreement with the abovementioned losses of mineral buffer from the soil. Simulation of the $\mathrm{CO}_{2}$ fluxes in the mesocosms suggested that such soil $\mathrm{C}$ losses may at least partially be explained by acidification due to aluminum hydroxide buffering, an important process in many Western Danish soils (Gundersen and Beier, 1988; Hansen and Postma, 1995; Kjøller et al., 2004).

By means of $\delta^{13} \mathrm{C}$ signatures, lime amendment of acidic soils has previously been shown to cause increases in the $\mathrm{R}_{\mathrm{S}}$ corresponding to 5-77\% of the ER (Bertrand et al., 2007; Biasi et al., 2008; Dumale et al., 2011; Tamir et al., 2011; Ahmad et al., 2013, 2014). There seems to be general consensus that degassing of lime-C by acid release from nitrification is the main driver behind a higher ER from limed soil (West and McBride, 2005; Oh and Raymond, 2006; Hamilton et al., 2007; Barnes and Raymond, 2009; Dumale et al., 2011). However, a large variation in the contribution of lime-derived $\mathrm{CO}_{2}$ to the total ER highlights the importance of possible interactions, such as the enhancement of biological processes (priming) under calcareous amendments due to an elevation in soil $\mathrm{pH}$ (Curtin et al., 1998; Biasi et al., 2008; Dumale et al., 2011; Ahmad et al., 2013, 2014) or temperature (Ahmad et al., 2014), or a stimulation of the plant biomass (Ahmad et al., 2013). The combined evidence from our study and those mentioned above indicates that calcareous amendments to any acidic soil increase the $R_{\mathrm{s}}$ far beyond any increase in the DIC percolation flux. This study and studies by Bertrand et al. (2007) and Ahmad et al. (2013) show that $R_{\mathrm{s}}$ increases can be substantial even when there is no acidification from nitrification that could cause degassing of DIC (i.e., when nitrate is the dominant $\mathrm{N}$ source for root uptake). Instead our results suggest a control by mineral equilibria and priming on vadose zone $\mathrm{C}$ cycling in amended acid soils. Additional research should be conducted to manifest these hypotheses.

The low soil trace element content in CCW treatments (Supplement, Table S1) suggests that the CCW had low contents of fly ash, slag, or other additives, with high levels of trace metal and silicate (Dhir and Limbachiya, 1999; Mehta and Monteiro, 2006). Amendment with more silicate-rich types of CCW may have resulted in lower increases in the inorganic $\mathrm{C}$ fluxes in the 
long term due to the slower weathering of silicates compared to portlandite (Appelo and Postma, 2005).

\section{Effect of Crushed Concrete Waste on Plant Growth}

The absence of adverse effects of CCW on plant growth was somewhat surprising and might be related to limited changes in the soil solution $\mathrm{pH}$, which only slightly exceeded the optimum range of 5.5 to 7.0 for cultivated plants (Enoch and Olesen, 1993). Another potential explanation is the absence of major changes in the soil content of trace elements (Supplement, Table S1). Increased aboveground biomass in the high CCW treatment (Table 1) may have been related to changed retention characteristics following $\mathrm{CCW}$ addition. Although a different $\mathrm{CCW}$ type might have affected plant growth differently, ecotoxic concrete additives such as fly ash (Dhir and Limbachiya, 1999) do not necessarily imply a negative effect on plant growth (Khan and Khan, 1996; Jala and Goyal, 2006). Plant growth responses to concrete amendment may furthermore be species and dose dependent, with levels $\leq 8 \%$ concrete in the soil being beneficial for the growth of most investigated species (Chen et al., 2013; Xu and Chen, 2012).

\section{Acknowlegdements}

The authors thank Nina Thomsen, Simon Svane, Mette Flodgaard, Anja Nielsen and Christina Lynge for skilled technical and laboratory support. The project was financed by the Danish Council for Strategic Research (DSF-09-067234).

\section{Supplement}

Figure $\mathrm{S} 1$ shows the spatial and temporal development of the soil VWC and temperature, soil air $p \mathrm{CO}_{2}$, and soil water alkalinity in the mesocosms. Table $\mathrm{S} 1$ shows the trace element content in the leachate from mesocosms. Text T1 comprises the modeling methodology and a description of the additional modeling studies presented in Fig. S2 through S9. Figures S2 and S3 show measured and simulated time courses of cumulative drainage and the VWC with depth in limed mesocosm 1 and low CCW mesocosm 1. Figure $\mathrm{S} 4$ shows the tracer $\left(\mathrm{Cl}^{-}\right)$movement over time in the modeled mesocosms. The simulated nutrient uptake in limed mesocosm 1 and low CCW mesocosm 1 is shown in Fig. $\mathrm{S} 5$ and S6, respectively. Fig. $S 7$ to $S 9$ show the remaining results from the two tested scenarios in limed and low CCW-amended mesocosms.

\section{References}

Ahmad, W., B. Singh, F.A. Dijkstra, and R.C. Dalal. 2013. Inorganic and organic carbon dynamics in a limed acid soil are mediated by plants. Soil Biol. Biochem. 57:549-555. doi:10.1016/j.soilbio.2012.10.013

Ahmad, W., B. Singh, F.A. Dijkstra, R.C. Dalal., and P. Geelan-Small. 2014. Temperature sensitivity and carbon release in an acidic soil amended with lime and mulch. Geoderma 214-215:168-176. doi:10.1016/j.geoderma.2013.09.014

Amundson, R.G., and E.A. Davidson. 1990. Carbon dioxide and nitrog enous gases in the soil atmosphere. J. Geochem. Explor. 38:13-41. doi:10.1016/0375-6742(90)90091-N

Andrews, J.A., and W.H. Schlesinger. 2001. Soil $\mathrm{CO}_{2}$ dynamics, acidification, and chemical weathering in a temperate forest with experimental $\mathrm{CO}_{2}$ enrichment. Global Biogeochem. Cycl. 15(1):149-162. doi:10.1029/2000GB001278
Appelo, C.A.J., and D. Postma. 2005. Geochemistry, groundwater and pollution. 2nd ed. A.A. Balkema Publishers, Leiden, The Netherlands.

Barker, T., I. Bashmakov, L. Bernstein, J.E. Bogner, P. Bosch, R. Dave, O. Davidson, B.S. Fisher, S. Gupta, K. Halsnaes, B. Heii, S.K. Ribeiro, S. Kobayashi, M.D. Levine, D.L. Martino, O. Masera, B. Metz, L. Meyer, G. Nabuurs, A. Najam, N. Nakicenovic, H.H. Rogner, J. Roy, J. Sathaye, R. Schock, P. Shukla, R.E.H. Sims, P. Smith, D.A. Tirpak, D. Urge-Vorsatz, and D. Zhou. 2007. Technical summary. In: B. Metz et al., editors, Climate change 2007: Mitigation of climate change. Contribution of Working Group III to the Fourth Assessment Report of the Intergovernmental Panel on Climate Change. Cambrigde University Press, Cambridge, UK. http://www.ipcc.ch/pdf/assessment-report/ar4/wg3/ar4wg3-ts.pdf (accessed 20 Oct. 2014).

Barnes, R.T., and P.A. Raymond. 2009. The contribution of agricultural and urban activities to inorganic carbon fluxes within temperate watersheds. Chem. Geol. 266:318-327. doi:10.1016/j.chemgeo.2009.06.018

Barraclough, P.B., and R.A. Leigh. 1984. The growth and activity of winter wheat roots in the field: The effect of sowing date and soil type on root growth of high-yielding crops. J. Agric. Sci. 103:59-74. doi:10.1017/ S002185960004332X

Bertrand, I., O. Delfosse, and B. Mary. 2007. Carbon and nitrogen mineralization in acidic, limed and calcareous agricultural soils: Apparent and actual effects. Soil Biol. Biochem. 39(1):276-288. doi:10.1016/j.soilbio.2006.07.016

Biasi, C., S.E. Lind, N.M. Pekkarinen, J.T. Huttunen, N.J. Shurpali, N.P. Hyvönen, M.E. Repo, and P.J. Martikainen. 2008. Direct experimental evidence for the contribution of lime to $\mathrm{CO}_{2}$ release from managed peat soil. Soil Biol. Biochem. 40:2660-2669. doi:10.1016/j.soilbio.2008.07.011

Bond-Lamberty, B., and A. Thomson. 2010. Temperature-associated increases in the global soil respiration record. Nature 464(7288):579-582. doi:10.1038/nature08930

Chen, F., Y. Xu, C. Wang, and J. Mao. 2013. Effects of concrete content on seed germination and seedling establishment in vegetation concrete matrix in slope restoration. Ecol. Eng. 58:99-104. doi:10.1016/j. ecoleng.2013.06.016

Claisse, P.A., H. El-Sayad, and I.G. Shaaban. 1999. Permeability and pore volume of carbonated concrete. ACl Mater. J. 96(3):378-381. doi: $10.14359 / 636$

Curtin, D., C.A. Campbell, and A. Jalil. 1998. Effects of acidity on mineralization: $\mathrm{PH}$-dependence of organic matter mineralization in weakly acidic soils. Soil Biol. Biochem. 30(1):57-64. doi:10.1016/S00380717(97)00094-1

Dhir, K.R., and M.C. Limbachiya. 1999. Utilizing ready-mixed concrete and mortar. Thomas Telford Publ., London, UK.

Dumale, W.A., Jr., T. Miyazaki, W.A. Dumale Jr., T. Miyazaki, K. Hirai, and T. Nishimura 2011. SOC turnover and lime- $\mathrm{CO}_{2}$ evolution during liming of an acid andisol and ultisol. OJSS 1:49-53. doi:10.4236/ojss.2011.12007

Enoch, H.Z., and J.M. Olesen. 1993. Plant-response to irrigation with water enriched with carbon-dioxide. New Phytol. 125(2):249-258. doi:10.1111/j.1469-8137.1993.tb03880.x

Gundersen, P., and C. Beier. 1988. Aluminum sulfate solubility in acid forest soils in Denmark. Water Air Soil Pollut. 39(3-4):247-261.

Haberle, J., P. Svoboda, and P. Ruzek. 1996. Root length of winter wheat and the content of mineral nitrogen in the soil profile. Plant Soil Environ. 42(5):193-197.

Hamilton, S. K., A. L. Kurzman, C. Arango, L. Jin, and G.P. Robertson. 2007. Evidence for carbon sequestration by agricultural liming. Global Biogeochem. Cycl. 21. doi:10.1029/2006GB002738).

Hansen, B.K., and D. Postma. 1995. Acidification, buffering, and salt effects in the unsaturated zone of a sandy aquifer, Klosterhede, Denmark. Water Resour. Res. 31 (11):2795-2809. doi:10.1029/95WR02217

Hanson, P.J., N.T. Edwards, C.T. Garten, and J.A. Andrews. 2000. Separating root and soil microbial contributions to soil respiration: A review of methods and observations. Biogeochemistry 48(1):115-146. doi:10.1023/A:1006244819642

Jacques, D., J. Šimůnek, D. Mallants, and M.Th. van Genuchten. 2008. Modeling coupled hydrologic and chemical processes: Long-term uranium transport following phosphorus fertilization. Vadose Zone J. 7:698-711. doi:10.2136/vzj2007.0084

Jakobsen, I., and N.E. Nielsen. 1983. Vesicular-arbuscular mycchoriza in fieldgrown crops. New Phytol. 93:401-413. doi:10.1111/j.1469-8137.1983. tb03440.x

Jala, S., and D. Goyal. 2006. Fly ash as a soil ameliorant for improving crop production-A review. Biosource Technol 97:1136-1147. doi:10.1016/j. biortech.2004.09.004 
Karberg, N.J., K.S. Pregitzer, J.S. King, A.L. Friend, and J.R. Wood. 2005. Soil carbon dioxide partial pressure and dissolved inorganic carbonate chemistry under elevated carbon dioxide and ozone. Oecologia 142:296-306. doi:10.1007/s00442-004-1665-5

Khan, M.R., and M.W. Khan. 1996. The effect of fly ash on plant growth and yield of tomato. Environ. Pollut. 92(2):105-111. doi:10.1016/02697491 (95)00098-4

Kjøller, C.. D. Postma, and F. Larsen. 2004. Groundwater acidification and the mobilization of trace metals in a sandy aquifer. Environ. Sci. Technol. 38(10):2829-2835. doi:10.1021/es030133v

Lal, R. 2008. Carbon sequestration. Philos. Trans. R. Soc. B 363(1492):815830. doi:10.1098/rstb.2007.2185

Lee, R.W. 1997. Effects of carbon dioxide variations in the unsaturated zone on water chemistry in a glacial-outwash aquifer. Appl. Geochem. 12(4):347-366. doi:10.1016/S0883-2927(97)00001-2

Lohila, A., M. Aurela, K. Regina, and T. Laurila. 2003. Soil and total ecosystem respiration in agricultural fields: Effect of soil and crop type. Plant Soil 251 (2):303-317. doi:10.1023/A:1023004205844

Loveys, B.R., I. Scheurwater, T.L. Pons, A.H. Fitter, and O.K. Atkin. 2002 Growth temperature influences the underlying components of relative growth rate: An investigation using inherently fast- and slowgrowing plant species. Plant Cell Environ. 25:975-987. doi:10.1046/j.13653040.2002.00879.x

Malhi, S.S., and K.S. Gill. 2002. Fertilizer $N$ and $P$ effects on root mass of bromegrass, alfalfa and barley. J. Sustain. Agric. 19(3):51-63. doi:10.1300/J064v19n03_06

Manning, D.A., and P. Renforth. 2013. Passive sequestration of atmospheric $\mathrm{CO}_{2}$ through coupled plant-mineral reactions in urban soils. Environ. Sci. Technol. 47(1):135-141. doi:10.1021/es301250

Marschner, H. 1995. Mineral nutrition of higher plants. Academic Press Ltd. London.

Marschner, H., M. Haussling, and E. George. 1991. Ammonium and nitrate uptake rates and rhizosphere $\mathrm{pH}$ in non-mycorrhizal roots of Norway spruce [Picea abies (L.) Karst.]. Trees 5:14-21. doi:10.1007/BF00225330

Mehta, P.K., and P.J.M. Monteiro. 2006. Concrete, microstructure, properties and materials. McGraw-Hill, New York.

Oh, N.-H. and P.A. Raymond. 2006. Contribution of agricultural liming to riverine bicarbonate export and $\mathrm{CO}_{2}$ sequestration in the Ohio River basin. Global Biogeochem Cycl. 20(3):GB3012. doi:10.1029/2005GB002565

Olesen, J.E., J.V. Mortensen, L.N. Jørgensen, and M.N. Andersen. 2000. Irrigation strategy, nitrogen application and fungicide control in winter wheat on a sandy soil. I. Yield, yield components and nitrogen uptake. J. Agric. Sci. 134:1-11. doi:10.1017/S0021859699007352

Pade, C., and M. Guimaraes. 2007. The $\mathrm{CO}_{2}$ uptake of concrete in a 100 year perspective. Cement Concr. Res. 37(9):1348-1356. doi:10.1016/j. cemconres.2007.06.009

Parkhurst, D., and C.A.J. Appelo. 2011. PHREEQC (Version 3)-A computer program for speciation, batch-reaction, one-dimensional transport and inverse geochemical calculations. USGS, Water Resources Div. Denver, CO.

Poorter, H., C. Remkes, and H. Lambers. 1990. Carbon and nitrogen economy of 24 wild species differing in relative growth rate. Plant Physiol. 94:621-627. doi:10.1104/pp.94.2.621

Raab, G.A., M.H. Bartling, M.A. Stapanian, W.H. Cole III, R.L. Tidwell, and K.A. Cappo. 1990. The homogenization of environmental soil samples in bulk. In: M.S. Simmons, editor, Hazardous waste measurements. CRC Press, Boca Raton, FL. p. 35-52.

Ravnskov, S., and I. Jakobsen. 1995. Functional compatibility in arbuscular mycorrhizas measured as hyphal $\mathrm{P}$ transport to the plant. New Phytol. 129:611-618. doi:10.1111/j.1469-8137.1995.tb03029.x

Renforth, P. 2011 . Silicate production and availability for mineral carbonation. Environ. Sci. Technol. 45:2035-2041. doi:10.1021/es103241w

Renforth, P., D.A.C. Manning, and E. Lopez-Capel. 2009. Carbonate precipitation in artificial soils as a sink for atmospheric carbon dioxide. Appl. Geochem. 24(9):1757-1764. doi:10.1016/j.apgeochem.2009.05.005

Robertson, P., E.A. Paul, and R.R. Harwood. 2000. Greenhouse gases in intensive agriculture: Contributions of individual gases to the radiative forcing of the atmosphere. Science 289(5486):1922-1925. doi:10.1126/ science.289.5486.1922

Schüßler, W., R. Neubert, I. Levin, N. Fischer, and C. Sonntag. 2000. Determination of microbial versus root-produced $\mathrm{CO}_{2}$ in an agricultural ecosystem by means of $d^{13} \mathrm{CO}_{2}$ measurements in soil air. Tellus $B$ 52:909-918. doi:10.1034/j.1600-0889.2000.d01-1.x

Simojoki, A., A. Jaakkola, and L. Alakukku. 1991. Effect of compaction on soil air in a pot experiment and in the field. Soil Tillage Res. 19:175-186. doi:10.1016/0167-1987(91)90085-C

Šimůnek, J., D. Jacques, M.Th. van Genuchten, and D. Mallants. 2006. Multicomponents geochemical transport modeling using Hydrus-1D and HP1. J. Am. Water Resour. Assoc. 42(6):1537-1547. doi:10.1111/j.1752-1688.2006.tb06019.x

Šimůnek, J., M. Šejna, H. Saito, M. Sakai, and M.Th. van Genuchten. 2013. The Hydrus-1D Software Package for Simulating the Movement of Water, Heat, and Multiple Solutes in Variably Saturated Media, Version 4.16, HYDRUS Software Series 3. Dep. of Environmental Sci., Univ. of California, Riverside.

Šimůnek, J., and D.L. Suarez. 1993. Modeling of carbon-dioxide transport and production in soil.1. Model development. Water Resour. Res. 29(2):487-497. doi:10.1029/92WR02225

Tamir, G., M. Shenker, H. Heller, P.R. Bloom, P. Fine, and A. Bar-Tal. 2011. Can soil carbonate dissolution lead to overestimation of soil respiration? Soil Sci. Soc. Am. J. 75(4):1414-1422. doi:10.2136/sssaj2010.0396

Thaysen, E.M., S. Jessen, P. Ambus, C. Beier, D. Postma, and I. Jakobsen. 2014a. Technical note: Mesocosm approach to quantify dissolved inorganic carbon percolation fluxes. Biogeosciences 11:1077-1084. doi:10.5194/bg-11-1077-2014

Thaysen, E.M., D. Jacques, S. Jessen, C.E. Andersen, E. Laloy, P. Ambus, D. Postma, and I. Jakobsen. 2014b. Inorganic carbon fluxes across the vadose zone of planted and unplanted soil mesocosms. Biogeosci. Discuss. 11:4251-4299. doi:10.5194/bgd-11-4251-2014

Tukey, J. 1953. Multiple comparisons. J. Am. Stat. Assoc. 48(263):624-625.

USDA. 1954. Methods for soil characterization. Diagnosis and improvement of saline and alkali soils. USDA Agric. Handbk. 60. USDA, U.S.S.L. Staff, Washington, DC, USA. p. 83-147.

Vermeulen, S.J., B.M. Campbell, et al. 2012. Climate change and food systems. Annu. Rev. Environ. Resour. 37:195-222. doi:10.1146/annurevenviron-02041 1-130608

Vrugt, J.A., B.A. Robinson, J.M. Hyman. 2009. Self-adaptive multimethod search for global optimization in real-parameter spaces. IEEE Trans. Evol. Comput. 13(2):243-259. doi:10.1109/TEVC.2008.924428

Walmsley, D.C., J. Siemens, R. Kindler, L. Kirwan, K. Kaiser, M. Saunders, M. Kaupenjohann, and B.A. Osborne. 2011. Dissolved carbon leaching from an Irish cropland soil is increased by reduced tillage and cover cropping. Agric. Ecosyst. Environ. 142(3-4):393-402. doi:10.1016/j. agee.2011.06.011

Welch, B.L. 1947. The generalization of "Student's" problem when several different population variances are involved. Biometrika 34(1-2):28-35 doi:10.1093/biomet/34.1-2.28

Weligama, C., P.W.G. Sale, M.K. Conyers, D.L. Liu, and C. Tang. 2010. Nitrate leaching stimulates subsurface root growth of wheat and increases rhizosphere alkalisation in a highly acidic soil. Plant Soil 328:119-132. doi:10.1007/s $11104-009-0087-x$

West, T.O., and A.C. McBride. 2005. The contribution of agricultural lime to carbon dioxide emissions in the United States: Dissolution, transport, and net emissions. Agric. Ecosyst. Environ. 108:145-154. doi:10.1016/j. agee.2005.01.002

Wilson, S.A., G.M. Dipple, I.M. Power, S.L.L. Barketer, S.J. Fallon II, and G. Southam. 2011. Subarctic weathering of mineral wastes provides as for atmospheric $\mathrm{CO}_{2}$. Environ. Sci. Technol. 45:7727-7736. doi:10.1021/ es202112y

XU, J.G., and N.G. Juma. 1992. Above- and below-ground net primary production of four barley (Hordeum vulgare L.) cultivars in western Canada. Can. J. Plant Sci. 72:1131-1140. doi:10.4141/cjps92-138

Xu, Y., and F. Chen. 2012. Effects of concrete content in vegetation concrete matrix on seed germination and seeding establishment of cynodon dactylon. Procedia Eng. 28:105-109. doi:10.1016/j.proeng.2012.01.690 